\title{
Indoor Smoke Exposure and Other Risk Factors of Pneumonia among Children Under Five in Karanganyar, Central Java
}

\author{
Atika Nikmah'), Isna Qadrijati²), Setyo Sri Rahardjo) \\ 1)Masters Program in Public Health, Universitas Sebelas Maret \\ 2) Faculty of Medicine, Universitas Sebelas Maret
}

\begin{abstract}
Background: Globally, pneumonia is an infectious disease with high morbidity and mortality rates. It causes one of five deaths in children under five years old worldwide. Approximately 61 million new cases of pneumonia in Sout East Asia occur annually. This study aimed to examine risk factors of pneumonia among children under five in Karanganyar, Central Java.

Subjects and Method: This was an analytic observational study with case control design. The study was conducted in Karanganyar District, Central Java, from October to November, 2017. Study subjects were selected by fixed disease sampling consisting of 68 children under five years old with pneumonia and 136 without pneumonia. The dependent variable was pneumonia. The independent variables were nutritional status, exclusive breastfeeding, maternal stress, type of labour, maternal education, maternal job status, family income, number of children, quality of house, quality of environment, and indoor smoke exposure. The data was collected by questionnaire and analyzed by path analysis.

Results: The risk of pneumonia increased with indoor smoke exposure $(b=2.57 ; 95 \% \mathrm{CI}=1.54$ to 3.60; $\mathrm{p}<0.001)$, number of children $\geq 3(\mathrm{~b}=1.34 ; 95 \% \mathrm{CI}=0.45$ to $2.24 ; \mathrm{p}=0.003)$, and maternal stres during pregnancy $(\mathrm{b}=1.02 ; 95 \% \mathrm{CI}=0.16$ to $1.88 ; \mathrm{p}=0.019)$. The risk of pneumonia decreased with good house environment $(b=-0.95 ; 95 \% \mathrm{CI}=-1.80$ to $-0.09 ; \mathrm{p}=0.030)$, healthy behavior $(b=-1.21 ; 95 \% \mathrm{CI}=-2.09$ to $-0.33 ; \mathrm{p}=0.007)$, and good nutritional status $(\mathrm{b}=-1.91 ; 95 \%$ $\mathrm{CI}=-2.92$ to $-0.90 ; \mathrm{p}<0.001)$. The risk of pneumonia was indirectly affected by exclusive breastfeding, history of Caesarean section, maternal education, maternal working outside the house, family income, and good quality of house.

Conclusion: The risk of pneumonia increases with indoor smoke exposure, but decreases with good house environment, healthy behavior, and good nutritional status.
\end{abstract}

Keyword: risk factor, pneumonia, children under five

Correspondence:

Atika Nikmah. Masters Program in Public Health, Universitas Sebelas Maret, Jl. Ir. Sutami 36 A, Surakarta 57126, Central Java. Email: atikanikmah123@gmail.com.

\section{BACKGROUND}

Good health is a fundamental right of every child worldwide. Children with poor health often get the infectious disease such as pneumonia. About 5.9 million children under five died in 2015 and nearly half were caused by pneumonia (14\%), diarrhea (10\%), malaria (7\%), AIDS (2\%) and measles (1\%) (WHO dan UNICEF, 2013; UNICEF, 2016a).
Pneumonia is an acute respiratory infection that adversely affects the lungs. It is caused by viruses, bacteria, or fungi. These infections are commonly spread from direct contact with infected persons, usually by hand or inhaling droplets due to coughing or sneezing (WHO, 2016a; Jones et al., 2016).

Pneumonia is an infectious disease that causes deaths among children under 
five. About 935,00o children died every year or equivalently more than 2,500 died per day (WHO, 2015). The World Health Organization estimates 156 million new cases of childhood pneumonia annually. About 20 million are severe cases and 61 million new cases occurred in Southeast Asia (Rudan 2008; Ferdous, 2014).

Africa (30\%) and Southeast Asia (39\%) were regions in the world with the highest incidence and severity of pneumonia cases (Zar et al., 2013). Basic Health Survey (RISKESDAS) conducted by Ministry of Health Indonesia reported that pneumonia prevalence among children under-five was $2.13 \%$ in 2007 and $1.8 \%$ in 2013 (Indonesia Ministry of Health, 2013). Incidence of pneumonia among infants in Indonesia reached 503,738 cases $(57.84 \%)$ in 2016 (Indonesia Ministry of Health, 2017).

The incidence of pneumonia cases in children under five in Central Java in 2016 was 20,662 (17.49\%) (Indonesia Ministry of Health, 2017). In 2016, there were 913 pneumonia cases in children under five (Karanganyar District Health Office, 2016). Based on a preliminary study conducted by Karanganyar District Health Office, the incidence of pneumonia among children under five from January to June 2017 was 304 cases.

Studies have shown, the risk factors for pneumonia in children in developing countries include malnutrition, lack of exclusive breastfeeding, incomplete measle immunization, premature birth, HIV infection, low family socioeconomics level, comorbidy, smoke exposure, and infection. Maternal education, vitamin A deficiency, as well as environmental factors such as indoor air pollution, occupancy density, and parental smoking, can increase the risk of child pneumonia. The indoor smoke exposure can stem from cooking and heating activities with biomass fuel (such as wood or dirt). Other diseases such as malaria and diarrhea can be important factors that contribute to the susceptibility to pneumonia among children under five in developing countries. A good understanding of risk factors for pneumonia is important to reducing morbidity and mortality rates of pneumonia among children under five (Wojsyk dan Bręborowicz, 2013; Roomaney et al., 2016; British Lung Foundation, 2016; Abuka, 2017; Caggiano et al., 2017).

According to Boccolini et al. (2011), death from pneumonia can be prevented by breastfeeding. Exclusive breastfeeding in developing countries can reduce the risk of diseases such as asthma and pneumonia. Pneumonia can also be prevented by pneumococcal vaccination and good nutritional status, which can be promoted by optimal breastfeeding practice and appropriate complementary feeding (Saha et al., 2016).

The high prevalence of pneumonia suggests that this problem should be addressed immediately using an appropriate model of assessing various factors, involving both direct and indirect relationships of variables. This study aimed to analyze psychological, environmental, and social risk factors on pneumonia, using path analysis model.

\section{SUBJECTS AND METHOD}

\section{Study design}

This was an analytic observational study with a case control design. The study was conducted in Jaten, Colomadu, and Mojogedang sub-districts, Karanganyar district, Central Java, from October to November 2017. Source population was children under five in Karanganyar district, Central Java. 
A sample of 204 children under five was selected for this study by fixed disease sampling consisting of 68 children with pneumonia and 137 children without pneumonia, with $1: 2$ ratio.

\section{Study variables}

The dependent variable was pneumonia. The independent variables were healthy behavior, nutritional status, stress during pregnancy, type of labor, exclusive breastfeeding, education, employment, family income, number of children, house environment, indoor smoking, and quality of house.

\section{Operational Definition of Variables}

Pneumonia was defined as children under five who suffered from prolonged cough, fever, and difficulty breathing diagnosed by doctor and based on medical assessment. The data were taken from medical record. The measurement scale was categorical, coded $O$ as non-pneumonia and 1 as pneumonia.

House environment was defined as the condition of facility and infrastructure in the residential environment such as drainage, clean water, waste management, and house condition. The data were collected by questionnaire and direct observation. The measurement scale was continuous, but for the purpose of data analysis it was transformed into dichotomous coded o for poor condition and 1 for good condition.

Healthy behavior was defined as personal hygiene which include proper manner in coughing, sneezing, and spitting inside the house, as well as opening window regularly. The data were collected by questionnaire. The measurement scale was continuous, but for the purpose of data analysis it was transformed into dichotomous coded $o$ for unhealthy behavior and 1 for healthy behavior.
Nutritional status was defined as the nutritional status of children under five calculated from weight for age (WAZ) measurement and compared with WHO Zscore. The data were taken from maternal and child monitoring book. The data were continuous, but for the purpose of data analysis it was transformed into dichotomous coded o for underweight and 1 for normal weight.

Indoor smoke was defined as the level of smoke exposure in the household coming from various sources such as kitchen stove and cigarette smoke. The data were collected by questionnaire. The measurement scale was continuous, but for the purpose of data analysis it was transformed into dichotomous coded o for low indoor smoke and 1 for high indoor smoke.

Maternal stress during pregnancy was defined as stressful conditions over the last 12 months triggered by a residential and cultural environment that disrupt maternal psychological state during pregnancy. The data were collected by questionnaire. The measurement scale was continuous, but for the purpose of data analysis it was transformed into dichotomous coded o for low stress and 1 for high stress.

Type of labor was defined as the type of labor chosen by the mother to deliver the infant. It involved the process of movement of the fetus, placenta, and membrane from the uterus by normal delivery or surgery. The measurement scale was categorical and coded $\mathrm{o}$ for normal delivery and 1 for Caesarean section.

Exclusive breastfeeding was defined as infant receiving only breast milk from birth to 6 months of age. No other liquids or solids are given - not even water - with the exception of oral rehydration solution, or drop/syrup of vitamin, mineral or medicine. The measurement scale was categorical and coded o for non exclusive 
Journal of Epidemiology and Public Health (2018), 3(1): 25-40

https://doi.org/10.26911/jepublichealth.2018.03.01.03

breastfeeding and 1 for exclusive breastfeeding.

Maternal education was defined as the highest attained formal education level by the mother. The measurement scale was categorical and coded o for <senior high school and 1 for $\geq$ senior high school.

Number of children was defined as the number of children who have been born by the mother. The measurement scale was continuous, but for the purpose of data analysis it was transformed into dichotomous coded o for $<3$ and 1 for $\geq 3$.

Maternal employment was defined as activities undertaken by mothers to generate income. The measurement scale was categorical and coded o for maternal working at house and 1 for maternal working outside the house.

Family income was defined as the average total of family member's income (in Rupiah) every month for the past six months. The measurement scale was continuous, but for the purpose of data analysis it was transformed into dichotomous coded o for low family income $(<\mathrm{Rp}$ $2,000,000)$ and 1 for high family income (Rp 2,000,000).

The quality of house was defined as house quality condition consisting of air humidity, home ventilation, sufficient light, and occupant density. The data were collected by questionnaire and direct observation. The measurement scale was continuous, but for the purpose of data analysis it was transformed into dichotomous coded o for low quality of house and 1 for high quality of house.

\section{Data analysis}

Multivariate analysis used path analysis model by Stata program. Path analysis used to determine the magnitude of direct and indirect effects of variables. Path analysis steps included model specification, model identification, model fit, parameter estimation, and respecification.

\section{Research ethics}

The research ethical clearance was granted from the Research Ethics Committee at Dr. Moewardi Hospital, Surakarta, Central Java, Indonesia. Research ethics included issues such as informed consent, anonymity, confidentiality, and ethical clearance.

\section{RESULTS}

\section{Sample characteristics}

Study subject characteristics are described in the Table 1. It shows that pneumonia among children was mostly in the age $\geq 24$ months, male, maternal education $<$ senior high school, and maternal working outside the house.

Table 1. Distribution of sample characteristics by case and control groups

\begin{tabular}{|c|c|c|c|c|c|}
\hline \multirow{2}{*}{ Characteristic } & & \multicolumn{2}{|c|}{ Case } & \multicolumn{2}{|c|}{ Control } \\
\hline & & $\mathbf{n}$ & \% & $\mathbf{n}$ & \% \\
\hline \multirow[t]{2}{*}{ Child age } & $<24$ months & 31 & $(45.6 \%)$ & 73 & $(53.7 \%)$ \\
\hline & $\geq 2$ & 37 & $(54.4 \%)$ & 63 & $(46.3 \%)$ \\
\hline \multirow{2}{*}{ Sex } & Female & 23 & $(33.8 \%)$ & 63 & $(46.3 \%)$ \\
\hline & Male & 45 & $(66.2 \%)$ & 73 & $(53.7 \%)$ \\
\hline \multirow[t]{2}{*}{ Maternal education } & $<$ senior high school & 37 & $(54.4 \%)$ & 53 & $(39.0 \%)$ \\
\hline & $\geq$ senior & 31 & $(45.6 \%)$ & 83 & $(61.0 \%)$ \\
\hline \multirow[t]{2}{*}{ Maternal employment } & Working in house & 32 & $(47.1 \%)$ & 88 & $(64.7 \%)$ \\
\hline & Working outside the house & 36 & $(52.9 \%)$ & 48 & $(35.3 \%)$ \\
\hline
\end{tabular}


Table 2 shows sample sociodemographic characteristics. This study selected sample by fixed disease sampling with case: control ratio $=1: 2$, resulting in 68 cases $(33.3 \%)$ of pneumonia and 136 controls (66.7\%). This high proportion of pneumonia cases does not necessarily reflect the true prevalence of pneumonia cases in the study population, but rather an implication of the way the sample was selected, i.e. fixed disease sampling.
The proportion of children exposed (48.5\%) and not exposed (51.5\%) to indoor smoke was about equal. The proportion of study subjects with healthy behavior (68.1\%) out-numbered those with unhealthy behavior (31.9\%). Likewise, families with $<3$ children (63.7\%) outnumbered those with $\geq 3$ children (36.3\%). Percent of children under study with normoweight (69.1\%) was higher than those with underwight (30.9\%).

Table 2. Sample sociodemographic characteristics

\begin{tabular}{|c|c|c|c|}
\hline & Variable & $\mathbf{n}$ & $\%$ \\
\hline \multirow[t]{3}{*}{1} & Pneumonia in children under five & & \\
\hline & No & 136 & 66.7 \\
\hline & Yes & 68 & 33.3 \\
\hline \multirow[t]{3}{*}{2} & Indoor smoke & & \\
\hline & Not exposed & 105 & 51.5 \\
\hline & Exposed & 99 & 48.5 \\
\hline \multirow[t]{3}{*}{3} & Environment quality & & \\
\hline & Good & 115 & 56.4 \\
\hline & Poor & 89 & 43.6 \\
\hline \multirow[t]{3}{*}{4} & Nutritional status & & \\
\hline & Normoweight & 141 & 69.1 \\
\hline & Underweight & 63 & 30.9 \\
\hline \multirow[t]{3}{*}{5} & Exclusive breastfeeding & & \\
\hline & Yes & 97 & 47.5 \\
\hline & No & 107 & 52.5 \\
\hline \multirow[t]{3}{*}{6} & Maternal stress during pregnancy & & \\
\hline & Low & 112 & 54.9 \\
\hline & High & 92 & 45.1 \\
\hline \multirow[t]{3}{*}{7} & Number of children & & \\
\hline & $<3$ & 130 & 63.7 \\
\hline & $\geq 3$ & 74 & 36.3 \\
\hline \multirow[t]{3}{*}{8} & Healthy behavior & & \\
\hline & Yes & 139 & 68.1 \\
\hline & No & 65 & 31.9 \\
\hline \multirow[t]{3}{*}{9} & Type of labor & & \\
\hline & Normal & 136 & 66.7 \\
\hline & Caesarean section & 68 & $33 \cdot 3$ \\
\hline \multirow[t]{3}{*}{10} & House quality & & \\
\hline & Good & 104 & 51.0 \\
\hline & Poor & 100 & 49.0 \\
\hline \multirow[t]{3}{*}{11} & Education & & \\
\hline & $\geq$ Senior high school & 114 & 55.9 \\
\hline & $<$ Senior high school & 90 & 44.1 \\
\hline \multirow[t]{3}{*}{12} & Employment status & & \\
\hline & Work inside house & 120 & 58.8 \\
\hline & Work outside house & 84 & 41.2 \\
\hline \multirow[t]{3}{*}{13} & Income & & \\
\hline & High $\geq$ Rp 2,000,000 & 105 & 51.5 \\
\hline & Low $<\mathrm{Rp} 2,000,000$ & 99 & 48.5 \\
\hline
\end{tabular}


Journal of Epidemiology and Public Health (2018), 3(1): 25-40

https://doi.org/10.26911/jepublichealth.2018.03.01.03

\section{Bivariate Analysis}

Figure 1 showed the difference in percent of Pneumonia case by indoor smoke exposure status. Percent of pneumonia case was much higher in the exposed group than the non-exposed group, suggesting that indoor smoke exposure is an important risk factor of pneumonia in children under five under study.

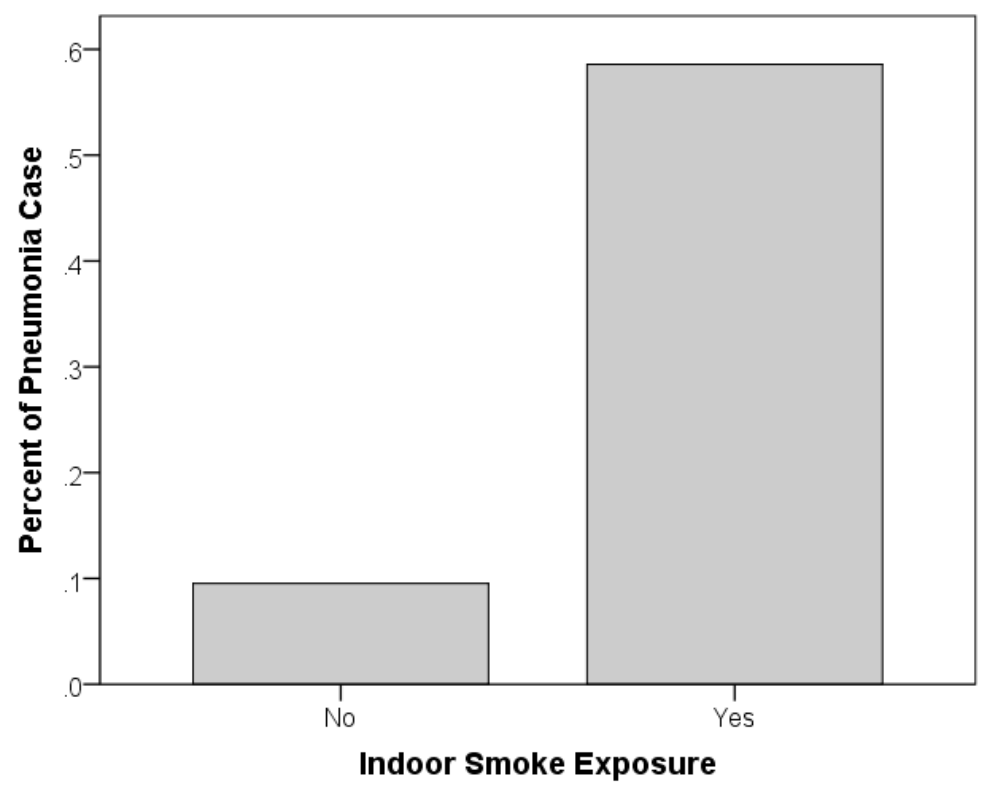

Figure 1. Difference in Percent of Pneumonia Case by Indoor Smoke Exposure Status

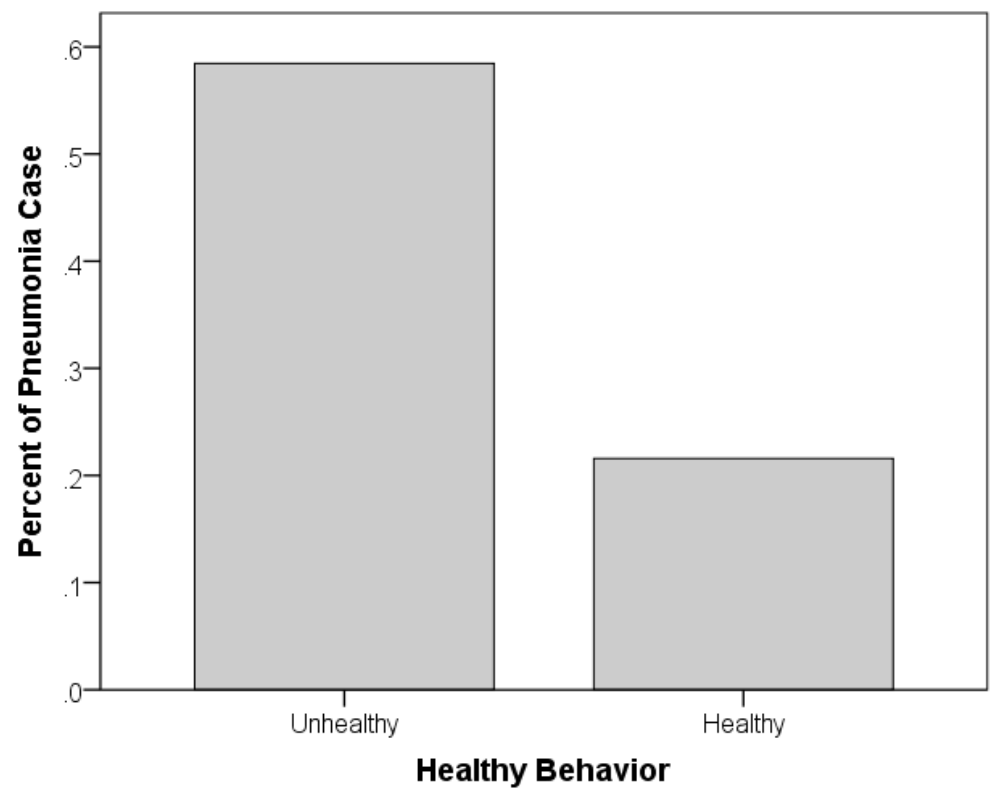

Figure 2. Difference in Percent of Pneumonia Case by Healthy Behavior Status 
Figure 2 showed the difference in percent of Pneumonia case by healthy behavior status. Percent of pneumonia case was much higher in the unhealthy behavior group than the healthy behavior group, suggesting that healthy behavior is an important risk factor of pneumonia in children under five under study.

\section{Path Analysis}

Path analysis model was run on Stata 13 program. The number of observed variable in the path model was 13, endogenous variables 8 , and exogenous variables 4 . Degree of freedom (df) value was 67 (over identified) indicating that path analysis model can be performed.

The path structural model with estimation is depicted in Figure 1. The results of path analysis model are reported in Table 2.

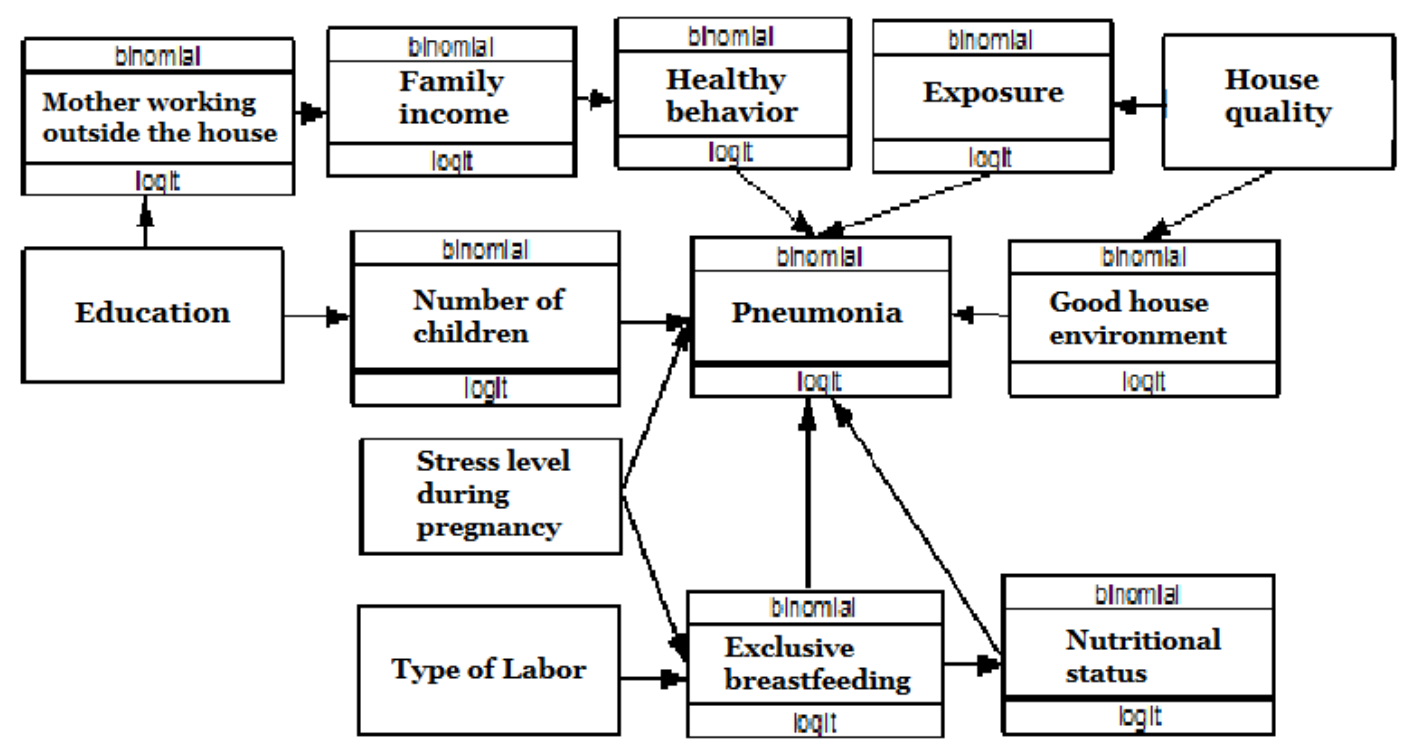

Figure 1. Structural model with estimate

Table 2 shows that indoor smoke $(b=2.57$; 95\% CI $=1.54$ to $3.60 ; \mathrm{p}<0.001)$ and number of children $\geq 3(b=1.34 ; 95 \% \mathrm{CI}=$ 0.45 to $2.24 ; \mathrm{p}=0.003$ ) increased the risk of pneumonia in children under five.

Good nutritional status $(b=-1.91$; 95\% $\mathrm{CI}=-2.92$ to $-0.90 ; \mathrm{p}<0.001)$, exclusive breastfeeding $(b=-1.19 ; 95 \% \mathrm{CI}=$ - 2.09 to $-0.28 ; \mathrm{p}=0.010$ ), low maternal stress during pregnancy $(\mathrm{b}=1.02 ; 95 \% \mathrm{CI}=$ 0.16 to $1.88 ; \mathrm{p}=0.019$ ), healthy behavior $(b=-1.21 ; 95 \% \mathrm{CI}=-2.09$ to $-0.33 ; \mathrm{p}=$ o.007), and good quality environment $(\mathrm{b}=$ $-0.95 ; 95 \% \mathrm{CI}=-1.80$ to $-0.09 ; \mathrm{p}=$ o.030) lowered the risk of pneumonia in children under five.
Exclusive breastfeeding increased nutritional status of children under five $(b=$ $0.65 ; 95 \% \mathrm{CI}=0.04$ to $1.26 ; \mathrm{p}=0.036)$.

Maternal stress during pregnancy $(b=$ $-0.65 ; 95 \% \mathrm{CI}=-1.22$ to $-0.08 ; \mathrm{p}=0.024)$ and Caesarean sectio $(b=-0.59 ; 95 \% \mathrm{CI}=$ -1.20 to <0.01; $\mathrm{p}=0.053$ ) lowered exclusive breastfeeding.

Good quality of house lowered indoor smoking $(b=-1.79 ; 95 \% \mathrm{CI}=-2.40$ to -1.19 ; $\mathrm{p}<0.001)$. Good quality house also increased environment quality $(b=1.53$; 95\% CI $=0.94$ to 2.13 ; $\mathrm{p}<0.001)$.

Maternal education $\geq$ senior high school lowered the likelihood of having children $\geq 3(b=-0.71 ; 95 \% \mathrm{CI}=-1.29$ to 0.14; $\mathrm{p}=$ 0.015). Maternal education 
Journal of Epidemiology and Public Health (2018), 3(1): 25-40

https://doi.org/10.26911/jepublichealth.2018.03.01.03

$\geq$ senior high school increased the likelihood of maternal working outside the house $(\mathrm{b}=0.67 ; 95 \% \mathrm{CI}=0.09$ to $1.24 ; \mathrm{p}=$ o.022). Maternal working outside the house increased family income $(b=0.89$; $95 \% \mathrm{CI}=0.31$ to $1.46 ; \mathrm{p}=0.002$ ).

High family income increased the likelihood of healthy behavior $(b=0.68$; $95 \% \mathrm{CI}=0.08$ to $1.27 ; \mathrm{p}=0.026$ ).

Table 2. The results of path analysis on the effects of indoor smoke exposure and other factors on the risk of Pneumonia in children under five

\begin{tabular}{|c|c|c|c|c|c|c|}
\hline \multirow{2}{*}{$\begin{array}{c}\text { Dependent } \\
\text { variable }\end{array}$} & & \multirow[b]{2}{*}{ Independent variable } & \multirow{2}{*}{$\begin{array}{c}\text { Path } \\
\text { analysis } \\
\text { coefficient }\end{array}$} & \multicolumn{2}{|c|}{ CI 95\% } & \multirow[b]{2}{*}{$\mathbf{p}$} \\
\hline & & & & $\begin{array}{c}\text { Lower } \\
\text { limit }\end{array}$ & $\begin{array}{c}\text { Upper } \\
\text { limit }\end{array}$ & \\
\hline \multicolumn{7}{|l|}{ Direct effect } \\
\hline Pneumonia & $\leftarrow$ & High indoor smoke & 2.57 & 1.54 & 3.60 & $<0.001$ \\
\hline Pneumonia & $\leftarrow$ & $\begin{array}{l}\text { Good house } \\
\text { environment }\end{array}$ & -0.95 & -1.80 & -0.09 & 0.030 \\
\hline Pneumonia & $\leftarrow$ & $\begin{array}{l}\text { Normal nutritional } \\
\text { status }\end{array}$ & -1.91 & -2.92 & -0.90 & $<0.001$ \\
\hline Pneumonia & $\leftarrow$ & Exclusive breastfeeding & -1.19 & -2.09 & -0.28 & 0.010 \\
\hline Pneumonia & $\leftarrow$ & $\begin{array}{l}\text { High stress level during } \\
\text { pregnancy }\end{array}$ & 1.02 & 0.16 & 1.88 & 0.019 \\
\hline Pneumonia & $\leftarrow$ & Number of children $\geq 3$ & 1.34 & 0.45 & 2.24 & 0.003 \\
\hline $\begin{array}{l}\text { Pneumonia } \\
\text { Indirect effect }\end{array}$ & Indirect effect & Healthy behavior & -1.21 & -2.09 & -0.33 & 0.007 \\
\hline $\begin{array}{l}\text { Normal nutritional } \\
\text { status }\end{array}$ & $\leftarrow$ & Exclusive breastfeeding & 0.65 & 0.04 & 1.26 & 0.036 \\
\hline $\begin{array}{l}\text { Exclusive } \\
\text { breastfeeding }\end{array}$ & $\leftarrow$ & $\begin{array}{l}\text { High stress level during } \\
\text { pregnancy }\end{array}$ & -0.65 & -1.22 & -0.08 & 0.024 \\
\hline $\begin{array}{l}\text { Exclusive } \\
\text { breastfeeding }\end{array}$ & $\leftarrow$ & Caesarean section labor & -0.59 & -1.20 & -0.00 & 0.053 \\
\hline High indoor smoke & $\leftarrow$ & Good quality of house & -1.79 & -2.40 & -1.19 & $<0.001$ \\
\hline $\begin{array}{l}\text { Good house } \\
\text { environment }\end{array}$ & $\leftarrow$ & Good quality of house & 1.53 & 0.94 & 2.13 & $<0.001$ \\
\hline $\begin{array}{l}\text { Number of children } \\
\geq 3\end{array}$ & $\leftarrow$ & $\begin{array}{l}\text { Maternal education } \\
\geq \text { senior high school }\end{array}$ & -0.71 & -1.29 & -0.14 & 0.015 \\
\hline $\begin{array}{l}\text { Mother working } \\
\text { outside the house }\end{array}$ & $\leftarrow$ & $\begin{array}{l}\text { Maternal education } \\
\geq \text { senior high school }\end{array}$ & 0.67 & 0.09 & 1.24 & 0.022 \\
\hline High family income & $\leftarrow$ & $\begin{array}{l}\text { Mother working outside } \\
\text { the house }\end{array}$ & 0.89 & 0.31 & 1.46 & 0.002 \\
\hline $\begin{array}{l}\text { Healthy behavior } \\
\text { N Observation }=204 \\
\text { Log Likelihood }=-110\end{array}$ & $\leftarrow$ & High family income & 0.68 & 0.08 & 1.27 & 0.026 \\
\hline
\end{tabular}

\section{DISCUSSION}

\section{The association between house environment condition and pneumonia}

The result of this study indicated that a good home environment decreases the incidence of pneumonia in infants. The result of this study is in line with the study by Wahyuningsih and Yulianti (2015) which states that a well-maintained home envi- ronment can prevent transmission of infectious diseases including Acute Respiratory Infection in infants.

The home environment as a determinant of human health includes clean water facilities, waste management, and healthy homes. Physical quality (infrastructure and utility devices), as well as the environment, have an important role in house settlements (Widjayanti, 2007). 
Good environmental condition can positively affect the realization of good health status. Conversely, a bad environment can trigger the occurrence of various diseases, especially infectious diseases (Fitriyani, 2008).

As much as $49.4 \%$ of the environmental condition of the house in the case (pneumonia) group was poor. Studies have found that the high incidence of pneumonia was caused by semi-permanent house. The location of the cattle stable was in the front yard, causing the smell of manure and making the air polluted. Garbage dumps were not available in some house environment and some people through garbage into the river near the house environment.

\section{The association between healthy behavior and pneumonia}

The result of this study indicated that healthy behavior that include coughing, sneezing, and spitting affect the decrease in the incidence of pneumonia in infants. The result of this study is in line with study by Luby (2005) which reported that healthy behavior that include coughing, sneezing, and spitting was associated with decreased incidence of pneumonia in infants.

According to Kamm et al. (2014), washing hands with soap can prevent child mortality caused by two major killer diseases of pneumonia and diarrhea. Handwashing behavior using soap with water can remove dirt and pathogen in the hand, physically it can reduce the transmission of pathogen. According to Ghimire (2012), hand hygiene and breathing are important in minimizing the spread of most of the infecting organisms of Upper Respiratory Tract Infection and pneumonia. Handwashing using water and soap can reduce the incidence of Upper Respiratory Tract Infection and pneumonia by $50 \%$.

\section{The association between nutrition- al status and pneumonia}

The result of this study indicated that normal nutritional status decreases the incidence of pneumonia in infants. The result of this study is consistent with Efni (2016) which stated that nutritional status is a risk factor for the pneumonia occurrence. Malnutrition inhibits the formation of specific antibodies and also interferes with lung defense. Bacteria or viruses easily enter the body of an individual with low body resistance or immunity. Poor nutritional status lowers the immune system and weakens the respiratory muscles, so children with poor nutrition status are more susceptible to Upper Respiratory Tract Infection compared with good nutritional status (Cheers, 2016).

Poor nutritional status can cause the child to become thin, weak, and susceptible to various infectious diseases caused by epithelial integrity and inflammation (Wicaksono, 2015). A lack of energy or protein intake is usually associated with a deficiency of certain vitamin and mineral. This problem often causes infectious diseases such as diarrhea and pneumonia of children under five. Children with poor nutritional status have a weaker immune response than those with good nutritional status, resulting in more severe infectious diseases (Ramezani, 2015).

The study found that as many as $55.6 \%$ of the pneumonia case group had poor nutritional status.

\section{The association between indoor smoke and pneumonia}

The result of this study indicate that exposure to household smoke increases the incidence of pneumonia in infants. This study is in line with Kumar's (2013) study which says that the probability of episodes of pneumonia is much higher in children 
from households using solid fuels for cooking than those of households using other fuels (OR 1.78; 95\% CI $=1.05$ to 2.99 ).

Air exposure in homes such as solid fuel use has been identified as one of the risk factors for pneumonia. Fuelwood or dried animal waste is commonly used for cooking in rural areas. Children and other family members living and sleeping under closed or semi-enclosed spaces are particularly vulnerable to exposure to particulate carbon monoxide, greenhouse gases, and other pollutants (Ghimire, 2012).

Smoking activities for family heads and siblings living in one house (grandfather, father or sibling's brother) can increase tobacco smoke. Cigarette smoke itself has a variety of particles, such as polycyclic hydrocarbons, carbon monoxide, nicotine, nitrogen oxides, and acrolein. Such particles can cause ciliated epithelial damage, decrease mucociliary clearance, suppress phagocyte activity, and bactericidal effects, thus disrupting the pulmonary defense system (Efni, 2016).

Praygod et al. (2016) suggest that indoor air pollution may increase the risk of pneumonia. Exposure to air pollutants contained in biomass fuel can increase epithelial respiratory attacks and weaken the immunity of the patient.

\section{The association between quality of house and pneumonia}

The result of this study indicates that good home quality decreases exposure to household fumes and improves the quality of the home environment. This study is in line with a study conducted by Juni (2016) which says that the quality of the home environment (wall type and the presence of the ceiling) and Khasanah (2016) which says that the environmental conditions in the house (the intensity of natural lighting, the type of wall house, cooking fuel is significantly associated with the incidence of pneumonia in infants.

In addition to malnutrition, a dense home environment can increase the spread of viruses and bacteria that indicate unhealthy home quality thereby contributing to an increased risk of childhood pneumonia (Thorn, 2011). Environmental conditions are an important component in the process of the occurrence of public health disorders. The low quality of the environment often results in high morbidity rates due to infectious diseases and parasites such as pneumonia (June, 2016). Home environment is influenced by the quality of the house, where the quality of healthy homes is one of the factors that affect the health of residents, especially in children under five. Healthy or not the house has a close relationship with infectious diseases, especially ISPA (Wahyuningsih and Yulianti, 2015).

This research is also in line with research conducted by Anggiani (2016) who said that the presence of smokers and the use of mosquito burns is related to the incidence of pneumonia. Where the house as a residence must meet the physical and biological requirements to be safe for the inhabitants. Anggiani also stated that risk factor of pneumonia incidence in under five can be influenced by unhealthy house condition has 1.7 bigger chance for the happening of pneumonia.

The type of fuel used for cooking is related to pollutants or substances that can cause air pollution inside the house, especially around the kitchen. High indoor air pollution from unqualified fuel such as fuel wood, charcoal and kerosene can cause respiratory tract irritation and affect specific and non-specific body defenses in the respiratory tract of infants against disease pathogens (Shani, 2015). 


\section{The association between maternal stress during pregnancy and pneu- monia}

The result of this study indicates that high pregnancy stress decreases exclusive breastfeeding which has an effect on increasing the incidence of pneumonia. This study is in line with the study conducted by Dozier (2012) which says that there is a relationship between stress and exclusive breastfeeding duration. This effect is seen in the long duration of breastfeeding is uncertain whereas breastfeeding activities are beneficial for the health of toddlers. Low family socioeconomic status resulted in pregnancy stress resulting in cessation of breastfeeding and disruption of breastfeeding $(\mathrm{OR}=1.82 ; 95 \% \mathrm{CI}=1.15$ to 2.88) $(\mathrm{OR}=2.80 ; 95 \% \mathrm{CI}=1.46$ up to 5.37$)$

High levels of husband and family support (such as emotional support, instrumental, and informed support) may increase breastfeeding duration. Such support is an important reason for the advancement in breastfeeding ( $\mathrm{Li}, 2008)$. Chronic stress is associated with serum cortisol levels that may affect the immune response as well as a shift in the production of protein molecules of cytokines that result in susceptibility to infection and lactation. Cytokines are derived from mammary epithelium, lymphocytes, and magrophages in milk where the lymphocyte immune system is responsible for stressors and the mechanisms that affect the production of cytokines in milk that can be affected by stress (Thibeau, 2016).

Breastfeeding improves cognitive abilities and reduces the risk of infectious diseases in children, but the effectiveness of administration depends significantly on the nutritional state of the mother. As nutritional need increases during pregnancy and breastfeeding, it is necessary to increase food consumption. Lack of macro and micro nutrients in breastfeeding women can lead to decreased micronutrient and volume of breast milk (Fledder-Johann, 2016).

\section{The association between Caesare- an section and pneumonia}

The result of this study indicates that the type of labor delivery (Caesarean section) decreases the likelihood of exclusive breastfeeding which eventually may increase the risk of pneumonia. This study is in line with the study conducted by Regan (2013) which reported that women who gave normal delivery are $47 \%$ more likely to breastfeed compared with women who delivered by Caesarean (OR=1.47; 95\% CI = 1.35 to 1.60$)$. The impact of Caesarean delivery is the delayed process of lactation so that many babies born through Caesarean delivery do not receive early support in obtaining breast milk that is used as a stimulator for intestinal health physiologically. Due to non-physiological colonization and early food support lost by delayed lactation may result in long-term effects. Caesarean delivery is also associated with infectious diseases such as maternal asthma and allergic rhinitis (Neu, 2011). Breastfeeding provides benefits to children's health where the chances of a child's respiratory illness are low. Babies born by Caesarean delivery tend not to be in direct contact with the skin. Skin-to-skin contact is a factor for early breastfeeding initiation and prolonged breastfeeding duration (Hobbs, 2016).

\section{The association between exclusive breastfeeding and pneumonia}

The result of this study indicates that exclusive breastfeeding improves the nutritional status that affects the decreased incidence of pneumonia. Research conducted by Sugihartono and Nurjazuli (2012) said that there is a relationship between breastfeeding with other fluids at the age of 
6 days to suffer from pneumonia. The practice of exclusive breastfeeding has a role in determining the infant's nutritional status, cognitive developmental disorders, and poor health conditions in the future (Kumar and Singh, 2015).

Nutrition and breastfeeding status are closely related. Exclusive breastfeeding for up to 6 months has a protective effect on the nutritional status of children and breast milk is indicated as a complete and nutritious food. Breastfeeding can be increased until the age of 2 years or older. Early weaning can make children susceptible to various diseases such as respiratory problems.

\section{The association between maternal education and pneumonia}

The result of this study indicates that higher maternal education increases the likelihood of having a job and decreases the number of children in the family. It in turn results in decreased incidence of pneumonia in children under five. This study is in line with the study conducted by Pradhan (2016) which reported that there is a relationship between maternal education and the level of knowledge. According to Kurniasari (2017), education affects knowledge, attitude, and skill, and it in turn affects income level. This means that on average the higher the level of one's education the more likely that person will earn a higher income (Tarigan, 2006).

\section{The association between mater- nal employment and pneumonia}

The result of this study indicates that work outside the home improves family income and improves the nutritional status of children under five which results in a decrease in the incidence of pneumonia toddlers. The result of this study is in line with Kosai's (2015) study which reported that there is a relationship between family income and the incidence of pneumonia ( $\mathrm{HR}=1.11 ; 95 \% \mathrm{CI}=1.02$ to 1.20$)$.

The relationship between socioeconomic status and death is most felt when income is an indicator of socioeconomic status in the family. This difference can be explained by differences in social support, pre-existing comorbidities and characteristics of infectious diseases suffered (Koch, 2013). The results of this study found that the work of mothers outside the home in the case group of $(42.9 \%)$ where mothers working outside the home is greater than working at home mother. Of the various types of work done by mothers have differences in income earned. Low incomes are generally closely related to many health problems faced, this is due to the inability and ignorance in overcoming such problems especially in health (Christi, 2015).

\section{REFERENCE}

Abuka T (2017). Prevalence of pneumonia and factors associated among children 2-59 months old in Wondo Genet district, Sidama zone, SNNPR, Ethiopia. Curr Pediatr Res, 21 (1): 19-25

Anggiani DR, Suhartono, Dewanti NAY (2016). Hubungan Kondisi Lingkungan dalam Rumah dengan Kejadian Pneumonia pada Balita di Wilayah Kerja Puskesmas Pati I Kabupaten Pati. Jurnal Kesehatan Masyarakat. 4 (3): 776-78. ISSN: 2356-3346

Boccolini CS, Carvalho ML, de Oliveira MIC, de dan Boccolini P, de MM. (2011). Breastfeeding can prevent hospitalization for pneumonia among children under 1 year old, Journal de Pediatria, 87(5): 399-404. doi: 10.2223/JPED.2136.

Breigeiron MK, Miranda MND, Souza AOWD, Gerhardt LM, Valente MT (2015). Association between nutri- 
tional status, exclusive breastfeeding and length of hospital stay of children, 36: 47-54. doi: 10.1590/1983-1447.2015.esp.57459.

British Lung Foundation (2015). What is Pneumonia?. Diakses dari http://www.healthline.com/health/pneumo nia? pada tanggal 24 April 2017.

Caggiano S, Ullmann N, de Vitis E, Trivelli M, Mariani C, Podagrosi M, Ursitti F, Bertolaso C, et al. (2017). Factors that negatively affect the prognosis of pediatric community-acquired pneumonia in district hospital in Tanzania, Int. J. Mol. Sci., 18(3). doi: 10.3390/ijms18030623.

Ceria I (2016). Hubungan faktor risiko intrinsik dengan kejadian pneumonia pada anak balita, Jurnal Medika Respati. 11(4). ISSN: 1907-3887.

Christi H, P Dina R, Nugraheni SA ( 2015). Faktor-faktor yang berhubungan dengan Kejadian ISPA pada Bayi Usia 6-12 bulan yang Memiliki Status Gizi Normal. Jurnal Kesehatan Masyarakat. 3(2): 107- 117. ISSN: 2356-3346.

Dinas Kesehatan Kabupaten Karanganyar. (2014). Profil Kesehatan Kabupaten Karanganyar Tahun 2014. (2015). Profil Kesehatan Kabupaten Karanganyar Tahun 2015. (2016). Profil Kesehatan Kabupaten Karanganyar Tahun 2016. (2017). Profil Kesehatan Kabupaten Karanganyar Tahun 2017.

Dozier AM, Nelson A, Brownell E (2012). The Relationship between Life Stress and Breastfeeding Outcomes among Low-Income Mothers. doi: 10.1155/2012/902487.

Efni Y, Machmud R, Pertiwi D (2016). Artikel Penelitian Faktor Risiko yang Berhubungan dengan Kejadian Pneumonia pada Balita di Kelurahan Air Tawar Barat Padang, 5(2): 365-370.
Ferdous F, Farzana FD, Ahmed S, Das SK, Malek MA, Das J, Faruque ASG, Chisti MJ (2014). Mother Perception and Healthcare Seeking Behaviour of Pneumonia Children in Rural Bangladesh. Hindawi Publishing Corporation. ISRN Family Medicine. 1-8. doi: 10.1155/2014/690315.

Fitriyani Y, Roosita K, Hartati Y (2008). Kondisi Lingkungan, Perilaku Hidup Sehat, dan Status Kesehatan Keluarga Wanita Pemetik Teh. Jurnal Gizi dan Pangan. 3(2): 86-93.

Fledderjohann J, Vellakkal S, Stuckler D (2016). Sexual \& Reproductive Healthcare Breastfeeding, pregnant, and non-breastfeeding nor pregnant women's food consumption: A matched within-household analysis in India. Elsevier BV, 7: 70-77. doi: 10.1016/j.srhc. 2015.11.007.

Ghimire M, Bhattacharya SK, Narain JP (2012). Pneumonia in South-East Asia Region: Public health perspective, 459-468.

Hobbs AJ, Mannion CA, Mcdonald SW, Brockway M, Tough SC (2016). The impact of caesarean section on breastfeeding initiation, duration and difficulties in the first four months postpartum, BMC Pregnancy and Childbirth. BMC Pregnancy and Childbirth, 1-9. doi: 10.1186/s12884016-0876-1.

Jones B, Dean N, Wunderink R, Sockrider $M$ (2016). What is Pneumonia. Am J Respir Crit Care Med. 193: 1-2.

Juni M (2016). Hubungan Faktor Kualitas Lingkungan Rumah dengan Kejadian Pneumonia pada Bayi di Wilayah Kerja Puskesmas Banjarmangu $1 \mathrm{Ka}-$ bupaten Banjarnegara. Jurnal Kesehatan Lingkungan Indonesia, 15(1): 6-13.

Kamm KB, Feikin DR, Bigogo GM, Aoi G, 
Audi A, Cohen AL, Shah MM, Yu J, Breiman RF, Ram PK (2014). Associations between Presence of Handwashing Station and Soap in the Home and Diarrhoea and Respiratory Illness, iin Children less than Five Years Old in Rural Western Kenya'. Trop Med Int Health. 19 (4): 398-406. doi: $10.1111 /$ tmi.12263

Kemenkes RI (2007). Laporan Riset Kesehatan Dasar. Jakarta: Badan Penelitian dan Pengembangan Kesehatan Kementerian Kesehatan Republik Indonesia.

(2013). Laporan Riset Kesehatan Dasar. Jakarta: Badan Penelitian dan Pengembangan Kesehatan Kementerian Kesehatan Republik Indonesia.

(2017). Data dan Informasi Profil Kesehatan Indonesia 2016.

Khasanah M, Suhartono, Dharminto. (2016). Hubungan Kondisi Lingkungan dalam Rumah dengan Kejadian Pneumonia pada Balita di Wilayah Kerja Puskesmas Puring Kabupaten Kebumen. Jurnal Kesehatan Masyarakat. 4(5): 27-34. ISSN: 2356-3346.

Koch K, Nørgaard M, Schønheyder HC, Thomsen RW, Søgaard M, Collaborative D dan Network B (2013). Effect of Socioeconomic Status on Mortality after Bacteremia in Working-Age Patients. A Danish Population-Based Cohort Study, 8(7). doi: 10.1371/journal.pone.0070082.

Kosai H, Tamaki R, Saito M, Tohma K, Alday PP (2015). Incidence and Risk Factors of Childhood Pneumonia-Like Episodes in Biliran Island, 1-19. doi: 10.1371/journal.pone.01 25009.

Kumar S, Bhukar JP (2013). Stress level and coping strategies of college students. Journal of Phsical Education and Sports Management. 4(1): 5-11. (2015). A Study of Exclusive Breast- feeding and its impact on Nutritional Status of Child in EAG States, 445(3): 435-445.

Kurniasari AD (2017). Hubungan Antara Tingkat Pendidikan, Pekerjaan dan Pendapatan Orang Tua Dengan Status Gizi Pada Siswa SD Hangtuah 6 Surabaya, Jurnal Pendidikan Olahraga dan Kesehatan. 5(2): 164-170.

Li J, Kendall GE, Henderson S, Downie J, Landsborough L, Oddy WH (2008). 'Maternal psychosocial well-being in pregnancy and breastfeeding duration. Journal Acta Pediatrica. doi: 10.1111/j.1651-2227.2007.00602.x

Luby SP, Agboatwalla M, Feikin DR, Painter J, Ms WB, Altaf A, Hoekstra RM. (2005). Effect of handwashing on child health: a randomised controlled trial. 366: 225-233.

Neu J, Rushing J (2011). Caesarean Versus Vaginal Delivery: Long Term Infant Outcomes and the Hygiene Hypothesis. Clin Perinatol. 38(2): 321- 331. doi: 10.1016/j.clp.2011.03.008.

Nguyen TKP, Tran TH, Roberts CL, Fox GJ, Graham SM, Marais BJ (2017). Risk factors for child pneumonia - focus on the Western Pacific Region, Paediatric Respiratory Reviews. Elsevier Ltd, 21: 95-101. doi: 10.1016/j.prrv.2016.07.002.

Pradhan SM, Rao AP, Pattanshetty SM, Nilima AR (2016). Knowledge and perception regarding childhood pneumonia among mothers of under five children in rural areas of Udupi Taluk, Karnataka: A cross sectional study, 35-39. doi: 10.4103/23495006.183690 .

Praygod G, Mukerebe C, Magawa R, Jeremiah K, Török ME (2016). Indoor Air Pollution and Delayed Measles Vaccination Increase the Risk of Severe Pneumonia in Children: Results from 
a Case-Control Study in Mwanza, Tanzania, 1-14. doi: 10.1371/journal.pone.0160804.

Ramezani M, Aemmi SZ, Moghadam ZE. (2015). Factors Affecting the Rate of Pediatric Pneumonia in Developing Countries: a Review and Literature Study', 3(24): 1173-1181.

Regan J, Thompson A, Defranco E (2013). 'The Influence of Mode of Delivery on Breastfeeding Initiation in Women with a Prior Caesarean Delivery, 8(2): 26-31. doi: 10.1089/bfm.2012.0049.

Roomaney RA, Pillay VWYKV, Awotiwon OF, Dhansay A, Groenewald P, Joubert JD, Nglazi MD, Nicol E, Bradshaw D (2016). Epidemiology of lower respiratory infection and pneumonia in South Africa (1997-2015): a systematic review protocol', BMJ Open, 6(9): e012154. doi: 10.1136/bmjopen2016-012154.

Rudan I, Boschi PC, Biloglav Z, Mulholland $\mathrm{K}$, Campbell H (2008). Epidemiology and etiology of childhood pneumonia, Bulletin of the World Health Organization, 86(5): 408-416. doi: 10.2471/BLT.07.048769.

Saha S, Hasan M, Kim L, Farrar JL, Hossain B, Islam M, Ahmed ANU, et al. (2016). Epidemiology and risk factors for pneumonia severity and mortality in Bangladeshi children \& lt;5 years of age before 10-valent pneumococcal conjugate vaccine introduction, BMC Public Health. BMC Public Health, 16(1): 1233. doi: 10.1186/s12889-016-3897-9.

Sugihartono dan Nurjazuli (2012). Analisis Faktor Risiko Kejadian Pneumonia Pada Balita Di Wilayah Kerja Puskesmas Sidorejo Kota Pagar Alam. Risk Factor Analysis Of Pneumonia Incidence On Under-Five-Year-Old Children In The Working Area Of Public
Health Center, Sidorejo, Pagar Alam City, Jurnal Kesehatan Lingkungan Indonesia. 11(1): 82-86.

Syani FE, Budiyono, Raharjo M (2015). Hubungan Faktor Risiko Lingkungan terhadap Kejadian Penyakit Pneumonia Balita dengan Pendekatan Analisis Spasial di Kecamatan Semarang Utara. Jurnal Kesehatan Masyarakat. 3 (3): 732-744. ISSN: 23563346

Tarigan R (2006). Pengaruh Tingkat Pendidikan terhadap Tingkat Pendapatan Perbandingan antara Empat Hasil Penelitian, Jurnal Wawasan: 11 (3): 21-27.

Thibeau S, Apolito KD, Minnick AF, Dietrich MS, Kane B, Cooley S, Groer $M$ (2016). Relationships of Maternal Stress with Milk Immune Components in African American Mothers: 11(1): 6-14. doi: 10.1089/bfm.2015.0117.

Thorn LKAM, Minamisava R, Nouer SS, Ribeiro LH, Andrade AL (2011). Pneumonia and poverty: a prospective population-based study among children in Brazil', BMC Infectious Diseases, 11(1): 180. doi: 10.1186/1471-2334-11-18o.

UNICEF (2016a). For every child, a fair chance. The promise of equity. Available at: http://www.unicef.org/publications/files/For_every_child_a _fair_chance.pdf.

Wahyuningsih A, Yulianti (2015). Perilaku Pemeliharaan Kesehatan dan Perilaku Kesehatan Lingkungan Berhubungan dengan Kejadian ISPA pada Balita. Jurnal Keperawatan. 1(2): 103-207. ISSN: 2407-7232.

Wicaksono H (2015). Nutritional Status Affects Incidence of Pneumonia in Underfives. Folia Medica Indonesiana. 51(4): 285-291. 
Journal of Epidemiology and Public Health (2018), 3(1): 25-40

https://doi.org/10.26911/jepublichealth.2018.03.01.03

Widjayanti (2007). Hubungan Kualitas Fisik dan Lingkungan dengan Pola Kehidupan Lansia di Kelurahan Pudak Payung Kecamatan Banyumanik, Semarang, Jurnal Ilmiah Perancangan Kota dan Permukiman. 6 (1): 40-49.

WHO, UNICEF (2013). Ending Preventable Child Deaths from Pneumonia and Diarrhoea by 2015. The integrated Global Action Plan for Pneumonia and Diarrhoea (GAPPD). ISBN 97892 41505239.

WHO (2015). World Pneumonia Day 2014 Pneumonia Fact Sheet 1 What is

"pneumonia?" Who, 6736 (October 2014).

WHO (2016a). Health Topic Pneumonia. Diakses dari http://www.who.int/topics/pneumococcal_infections /en/ pada 20 April 2017.

Wojsyk BI dan Breborowicz A (2013) Pneumonia in children. doi: 10.5772/54052.

Zar HJ, Madhi SA, Aston SJ, Gordon SB (2013). Pneumonia in low and middle income countries: progress and challenges, 1052-1056. doi: 10.1136/thoraxjnl-2013-204247. 